\title{
Influence of Addition Contents of Iron Ore Tailings on Structural Mortar
}

\author{
Nara Linhares Borges de Castro ${ }^{1}$, Bruna Silva Almada ${ }^{1}$, Abner Araújo Fajardo ${ }^{1}$, Carlos Augusto Oliveira ${ }^{2}$ \& \\ White José dos Santos ${ }^{2}$ \\ ${ }^{1}$ Department of Materials Engineering and Construction, Federal University of Minas Gerais, Belo Horizonte, \\ Brazil \\ ${ }^{2}$ Federal University of Itajubá, Itajubá, Brazil \\ Correspondence: White José dos Santos, Department of Materials Engineering and Construction, Federal \\ University of Minas Gerais, Belo Horizonte, Brazil. E-mail: white.santos@demc.ufmg.br
}

Received: December 29, 2020 Accepted: January 30, $2021 \quad$ Online Published: February 9, 2021

doi:10.5539/jms.v11n1p74 URL: https://doi.org/10.5539/jms.v11n1p74

\begin{abstract}
This study discusses and analyzes an alternative of IOT reuse as addition in structural mortars, evaluating the influence of IOT addition contents. The material was physically and chemically characterized. Structural mortars were molded with $10 \%, 20 \%, 30 \%$ and $40 \%$ of addition of IOT in relation to cement mass. We investigate physical properties, mechanical indicators, durability indicators and microstructure. The tailings are composed of predominantly quartz, hematite and goethite, and no components were found that could compromise the cementitious composites. The addition of IOT provided a tendency to reduce open porosity. The addition of $30 \%$ IOT was the most efficient in closing pores. All addition contents led to the maintenance or gains in mechanical properties, and a 10\% gain in flexural tensile strength was observed for the addition of $10 \%$ IOT. The addition of $40 \%$ IOT promoted a $14 \%$ gain in compressive strength and maintenance of flexural tensile strength. This addition content evidences that the carbonation depth was not significantly affected. Based on the results, the addition percentages of $30-40 \%$ are interesting as to the analyzed properties.
\end{abstract}

Keywords: reuse of tailings, iron ore tailings, structural mortar

\section{Introduction}

The mining sector is of great importance. It contributes strongly to the economy of Brazil. Iron is the main mineral extracted and exported. According to the Brazilian Mining Institute (IBRAM, 2018), 430 million tons of iron ore were produced in 2017 alone, and almost $90 \%$ of this amount was exported. Thus, Brazil occupies a prominent position as the world's third largest producer and exporter of iron ore, following only China and Australia (National Mining Agency [ANM], 2018). With such an intense activity, large amounts of tailings are generated by the extraction (sterile) and beneficiation (tailings) of the ore depending on the deposit and the mining company. It is estimated that, on average, each ton of ore extracted generates $400 \mathrm{~kg}$ of tailings during the beneficiation process (Dauce, Castro, Lima, \& Lima, 2018).

Iron ore tailings consist mainly of the chemical elements $\mathrm{Si}, \mathrm{Fe}$ and $\mathrm{Al}$ (Cancio et al., 2018; Osinubi, Yohanna, \& Eberemu, 2015). In the case of tailings generated from sludge, the particle size composition may have a fine fraction $(\leq 10 \mu \mathrm{m})$ (Dauce et al., 2018). Although not considered toxic by the Brazilian Association of Technical Standards (ABNT, 2004) IOT can cause several environmental impacts, especially associated with the risk of tailing dam ruptures, a common disposal method. In recent years, several dam disruptions have occurred, causing major environmental and social impacts, such as the case of Mariana in 2015, where two dams broke releasing 62 million cubic meters of tailings and reaching areas as far as $100 \mathrm{~km}$ from the dam site (G1, 2015). In this sense, the use of iron mining tailings is of great importance.

In addition, the search for less expensive raw materials with similar mechanical and durability characteristics for application in cementitious materials, as highlighted by Zhao, Fan and Sun (2014), is a motivation for the use of IOT in these materials. According to Carrasco et al. (2016), IOT have been shown to be technically, economically and environmentally viable to produce cementitious matrices. They can be used in the manufacture of mortars (Carrasco et al., 2016; Fontes, Mendes, Silva, \& Peixoto, 2016; Ferreira, Aguiar, Oliveira, Silva, \& 
Pere, 2016; Magalhães et al., 2017; Ullas \& Venkatarama, 2010), concrete (Shettima, Hussin, \& Mirza, 2016; Kuranchie et al., 2015; Costa, Gumieri, \& Brandao, 2014), and ultra-high-performance concrete (Zhao et al., 2014). The results point to a good performance of composites, such as the maintenance of self-compacting concrete strength around $40 \mathrm{MPa}$, as observed by Shrivastava et al. (2016), using mud IOT as a fine aggregate; increased compressive strength, as verified by Abdulrahman (2015) who applied tailings in replacement for natural sand at different levels $(10 \%, 20 \%, 30 \%$ and $40 \%)$ for making concrete blocks and maintaining and improving mechanical properties and durability of structural mortars $(\approx 40 \mathrm{MPa})$ by the replacement $(20 \%, 40 \%$, $60 \%, 80 \%, 100 \%$ ) of natural aggregates for tailings, as reported by (Ugama \& Ejeh, 2014).

In general, IOT are used as an aggregate due to the high quartz content in their composition and because they are relatively inert in particle sizes close to that of sand (Zhao et al., 2014), allowing the reduction of natural sands exploration in riverbeds. However, the presence of very fine particles may cause the residue to act as an addition substance in cementitious matrices, thus requiring a simple adjustment of particle size (Jena et al., 2015). Aristimunho and Bertocini (2012) verified that the addition of $8 \%$ of ore tailings allowed the maintenance of workability and caused an approximately $40 \%$ increase in mortar compressive strength. However, the study of physical properties, durability and microstructure of composites was not addressed by the authors. The use of IOT as an additive has been little explored in the literature, requiring further studies especially with regard to these properties.

Considering the volume of iron ore tailings and their physical and chemical characteristics similar as the materials used to make cementitious composites, the objective of this study is to characterize IOT and to study the influence of the addition contents of this residue to structural mortars. For this, the physical and mechanical properties, durability indicators and the microstructure of structural mortars at $10 \%, 20 \%, 30 \%$ and $40 \%$ of addition of IOT in relation to the cement mass were evaluated. Thus, we suggest an alternative using IOT, allowing the mitigation of environmental impacts associated with them, as well as the production of a new product for construction with similar or better properties than those available on the market.

\section{Materials and Method}

In order to evaluate the performance of structural mortars made using the addition of iron mining tailings, an experimental program was elaborated considering the study of physical characterization of the materials used and some properties of the product (structural mortar) in its fresh and hardened state.

\subsection{Materials}

A Portland CPV-ARI cement was used as a binder as it contains low content of additions and. The standard Brazilian standard sand was used as an aggregate (IPT-Institute for Technological Research), which follows the particle size established by the (ABNT, 2015a).

Iron ore tailings came from the Engenho Seco Mine located in the municipality of Sarzedo, MG, Brazil, explored by the mining company Itaminas Comércio de Minérios S/A. The beneficiation process used by the mining company consists of crushing, washing and screening, and the tailings are disposed of directly in mud dams, from which they are collected by an employee.

The tailings received for the present work had characteristics similar as those of sands, showing noticeably larger and predominant grains throughout the sample. In order to use the material as an additive, it was necessary to comminute it until it reached an adequate particle size $(<150 \mu \mathrm{m})$. A grinding process was applied to the material using 14,000 turns in a SONNEX I-4205 ball mill, PAVITEST, manufactured by Contenco.

\subsection{Experimental Program}

The tailings were characterized as to particle size and real specific mass in their natural condition after the comminution process. The chemical and mineralogical composition, specific surface area and pore distribution were determined only with a particle material $<150 \mu \mathrm{m}$. The particle size was determined by sieving and sedimentation according to the (ABNT, 2016a), and the actual density was determined by pycnometry in water according to the Department of Roads Running (DNER, 1994). The chemical composition was determined by X-ray fluorescence (XRF) by the company Geosol, in Vespasiano, MG, Brazil, with a detection limit of $0.01 \%$ in the quantification. The mineralogical composition was obtained by X-ray diffraction (XRD) at the UFMG Department of Mining Engineering X-ray Laboratory using a Philips-PANalycal PW1710 diffractometer, CuKa radiation $\left(\lambda=1.54 \AA\right.$ ) and step of $0.06^{\circ} \mathrm{s}-1$. The phase identification was based on the Crystallography Open Database (COD) and the Rietveld refinement method for quantitative analysis of mineral phases.

For surface area analysis and pore distribution, the gas adsorption technique was used by applying the Brunauer, Emmett and Taller (BET) and Functional Density Theory (DFT) methods, respectively. The analysis was 
performed at the CEFET-MG Federal Center for Technological Education of Minas Gerais, using the equipment Quantachrome NovaWin - Data Acquisition and Reduction, Nova Instruments. The analyzed sample was previously heated in vacuum at $120^{\circ} \mathrm{C}$ for $24 \mathrm{~h}$ to remove impurities, and then subjected to a $\mathrm{N}^{2}$ (g) sorption process.

To evaluate the influence of the presence of IOT in the cementitious microstructure, a cement paste was replaced for $50 \%$ IOT in relation to the cement mass and reference paste (without addition). The value of 50\% IOT was adopted in order to maximize possible reactions and/or changes caused by the material. The microstructure and the formation of hydrated compounds were evaluated after 28 days using a FIB - Quanta FEG 3D FEI scanning electron microscope. The images were obtained with a 5-kV secondary electron detector. A carbon coating $15 \mathrm{~nm}$ thick was used in the broken section of the pastes.

In order to evaluate the properties of structural mortars with different addition contents, both fresh and hardened, mortars were made with the addition of IOT (only material smaller than $150 \mu \mathrm{m}$ ) at 10\%, 20\%, 30\% and $40 \%$ of contents in relation to the cement mass. Three specimens were shaped for each assay and content analyzed. The results were compared with the reference mortar (without the addition of IOT). The 1:3 ratio (cement: fine aggregate) was adopted. The water/cement factor was set at 0.50 in order to keep the highest possible number of variables constant and to identify the effects of adding IOT to the structural mortar formulation.

For the fresh state, the consistency was analyzed by flow table as recommended by the (ABNT, 2016b), and the mass density in the fresh state was analyzed as recommended by (ABNT, 2005a). For hardened state analyses, prismatic specimens $(4 \times 4 \times 16) \mathrm{cm}^{3}$ were molded according to the (ABNT, 2005b) which were used for mechanical properties study assays. Both compressive strength and flexural tensile strength were determined at the ages seven and 28 days using an EMIC automatic press, DL2000, capacity of $2.000 \mathrm{kN}$. Then, $5 \times 10-\mathrm{cm}$ cylindrical specimens were made for the determination of water absorption, porosity and specific mass according to the (ABNT, 2009) using $0.01 \mathrm{~g}$ precision scales. Additionally, we decided to evaluate the propensity to carbonate mortars. From the results of mechanical strength and porosity, we defined that the $40 \%$ content was the most suitable to perform the carbonation test, as it incorporates the largest amount of IOT. Given this, this durability test was performed only with this addition content because a behavior similar as the linear was perceived in the analyzed properties and, thus, the analysis of this content evaluates the most critical/extreme situation. For this, a prismatic specimen $(4 \times 4 \times 16) \mathrm{cm}^{3}$ was used, which was placed in a carbonation chamber at a concentration of $5 \% \mathrm{CO}_{2}$ and an average temperature of $25^{\circ} \mathrm{C}$ for 60 days. After this period, the specimen was cut longitudinally with a saw, and immediately sprayed with a $1 \%$ phenolphthalein indicator solution. Carbonated depth was read using a caliper 30 minutes after spraying the solution.

\section{Results and Discussion}

\subsection{Tailings Characterization}

\subsubsection{Chemical and Mineralogical Analysis of Mining Tailings and Cement}

The chemical analysis of IOT by XRF, as shown in Table 1, shows that the tailings consist mainly of $\mathrm{SiO}_{2}$ (27.41\%) and $\mathrm{Fe}_{2} \mathrm{O}_{3}$ (63.27\%). These results, when compared with those of (Fontes et al., 2019) indicate a great variability of iron ore tailings regarding chemical composition, as reported by (Galvão et al., 2018).

Table 1. Chemical composition of materials

\begin{tabular}{|c|c|c|c|c|c|c|c|c|c|c|c|c|}
\hline Material & $\mathrm{FeO}$ & $\mathrm{SiO}$ & $\mathrm{Al} \mathrm{O}$ & $\mathrm{Fe} \mathrm{O}$ & $\mathrm{CaO}$ & $\mathrm{MgO}$ & $\mathrm{TiO}$ & $\mathrm{P} \mathrm{O}$ & $\mathrm{Na} \quad \mathrm{O}$ & $\mathrm{K} \mathrm{O}$ & $\mathrm{MnO}$ & LOI \\
\hline IOT & 0.52 & 27.41 & 3.35 & 63.27 & 4.12 & 0.25 & 0.15 & 0.17 & 0.11 & 0.41 & 0.25 & 6.12 \\
\hline Cement & 0.18 & 21.95 & 5.07 & 3.03 & 65.96 & 1.85 & 0.25 & 0.25 & 0.24 & 1.04 & 0.18 & 5.24 \\
\hline
\end{tabular}

Note. LOI - Loss on ignition.

For the tailings used in this work, we also noticed a high iron content, which is justified due to the simplified beneficiation process to which the ore extracted from the mine was submitted. This variability is due to the beneficiation process used, the type of mineral that compose the mining, and its disposal position in the tailing dam (Carrasco et al., 2016, Fontes et al., 2016). Previous works reported using iron ore tailings, such as (Fontes et al., 2016). They also reported that the deposit site may affect the variability of the particle size and mineralogical and structural characteristics of the tailings in function of the variables that control the processes of mud discharge (Galvão et al., 2018). Therefore, it is important to survey the characteristics of the dam, as well as the IOT beneficiation process, as processes with different discharges and characteristics can present very different results for the same manufactured product. 
Regarding the chemical composition of the CPV-ARI cement, the material used complies with the standard (ABNT, 2018), presenting more than $85 \%$ of clinker and calcium sulfates with a magnesium oxide content lower than $2 \%$ in mass. X-ray diffractometry (Figure 1) determined the main mineral phases of IOT.

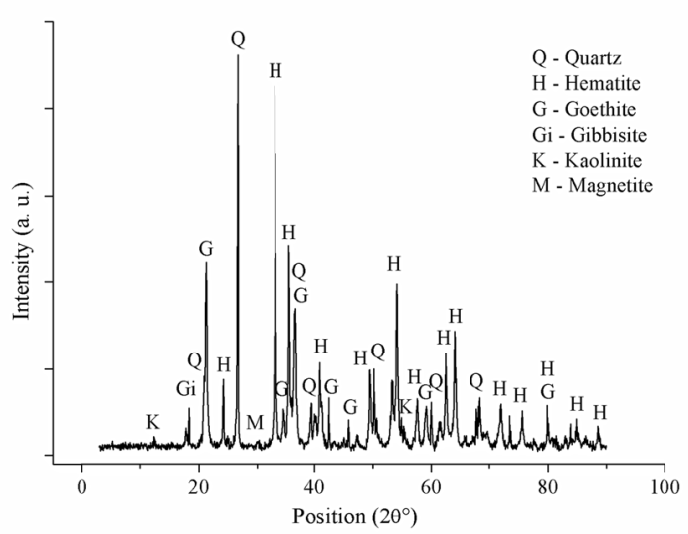

Figure 1. IOT X-ray spectrometry

The quantitative analysis (Figure 1) indicated the presence of goethite $(\mathrm{FeO}(\mathrm{OH}))$ at $39.2 \%$, hematite $(\mathrm{Fe} \mathrm{O}$ ) at $36.1 \%$, and quartz $(\mathrm{SiO})$ at $21.7 \%$ as predominant materials, gibbsite $(\mathrm{Al}(\mathrm{OH}) \quad$ ) at $2 \%$, and traces $(<1 \%)$ of kaolinite $\left(\mathrm{Al}_{2} \mathrm{O}_{3} \cdot 2 \mathrm{SiO}_{2} \cdot 2 \mathrm{H}_{2} \mathrm{O}\right)$ and magnetite $\left(\mathrm{Fe}_{3} \mathrm{O}_{4}\right)$. As the number of phases identified in the material is high, the Rietveld refinement has a lower precision and the quality indexes Rwp and GOF obtained in the test were $22.27 \%$ and 1.56 , respectively. The results show that the tailings are basically composed of Fe (iron) and $\mathrm{Si}$ (silicon), with small portions of other minerals, which is consistent with the XRF results. There are several peaks demonstrating the high crystallinity of the mining tailings and possibly little likelihood of a reaction of this material with those present in cementitious composites, as observed by (Florindo, 2019).

\subsubsection{Particle Size of the Residue}

In the study of the particle size composition of the material, it was identified that it, in natural condition, was unfavorable to the use as an addition to cement (fine sand). The use of finer particle size tailings, with $50 \%$ of the material passing through the $0.15 \mathrm{~mm}$ mesh sieve, has the greatest potential for mass addition or replacement in the production of IOT-added concretes, mortars and pastes (Zhao et al., 2014; Campanha, 2014). After comminution of the material for particle diameter adjustment, the final particle size distribution was determined as shown in Figure 2 and Table 2. There is an increase in the fineness percentage of the material obtained, providing a $68.4 \%$ use of the material called "thin" $(<0.15 \mathrm{~mm})$ and, consequently, an increase in the specific area. Only this material was applied during the manufacture of structural mortars and pastes.

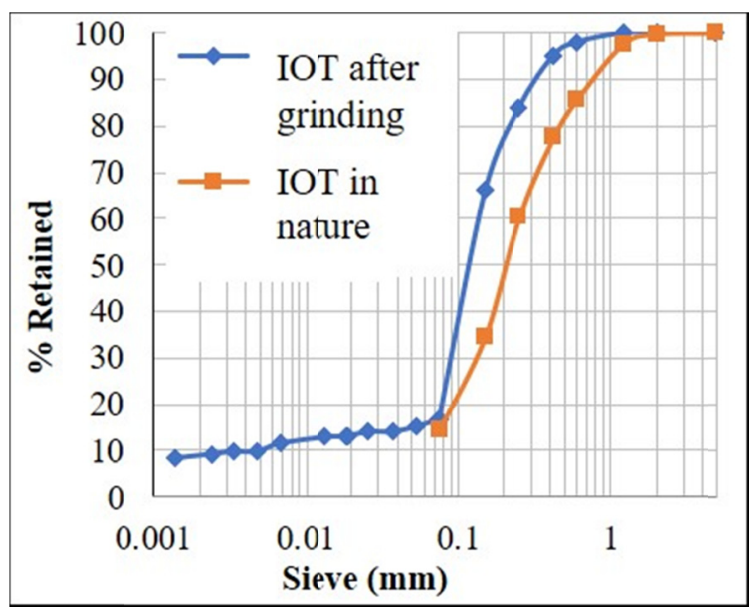

Figure 2. IOT particle size adjustment 
Table 2. Analysis $\mathrm{D}_{10}, \mathrm{D}_{50}, \mathrm{D}_{90}$ and average tailing diameter

\begin{tabular}{lll}
\hline & in natura & Comminution \\
\hline $\mathrm{D}_{10}(\mu \mathrm{m})$ & - & 6 \\
$\mathrm{D}_{50}(\mu \mathrm{m})$ & 22 & 13 \\
$\mathrm{D}_{90}(\mu \mathrm{m})$ & 78 & 31 \\
\hline
\end{tabular}

The grinding process using the ball mill after 14,000 cycles proved to be adequate, allowing a greater use of the material to make structural mortars. Studies have shown that for a same water/cement ratio, reducing the average particle size generally results in a higher hydration rate and thus better properties and higher strengths at the early ages (Castro, Liborio, \& Pandolfelli, 2009). The difficulty in grinding this material may be associated with the mineralogical composition of IOT, which contains high hardness minerals, such as hematite, quartz, goethite and magnetite. However, there is a tendency in research (Zhao et al., 2014; Campanha, 2014) to use materials with higher fine material contents.

The density obtained from the comminuted material was $4.04 \mathrm{~g} / \mathrm{cm}^{3}$, higher than conventional cements $(\approx 3.17$ $\mathrm{g} / \mathrm{cm}^{3}$ ) (Almada et al., 2020). However, it is close to the IOT studied (Zhao et al., 2014; Campanha, 2014). It is believed that the use of this material as a mineral addition at high values could greatly affect the final density of cementitious composites, which could increase the overload on structural elements and foundations.

The specific surface values of tailings in the natural state were $5.83 \mathrm{~m}^{2} / \mathrm{g}$ and, after comminution, the surface area increased by $33.62 \%$, resulting in $7.79 \mathrm{~m}^{2} / \mathrm{g}$. The surface area of comminuted tailings is larger than that of CP V - ARI cement $\approx 1.1 \mathrm{~m}^{2} / \mathrm{g}$, according to Medeiros et al. (2016), proving to be a finer material and, therefore, tending to require more kneading water. Porosimetry results (Figure 3 ) showed that the average pore volume was $0.036 \mathrm{cc} / \mathrm{g}$ under the maximum detection limit of this assay (1.993\%). The highest concentration of pore volume is around the $26 \AA$, demonstrating that it is a material characterized mainly by mesopores (IUPAC classification). Pores of similar dimensions can be noticed in the work of (Costa et al., 2014) who studied concretes with application of tailings of sinter feed.

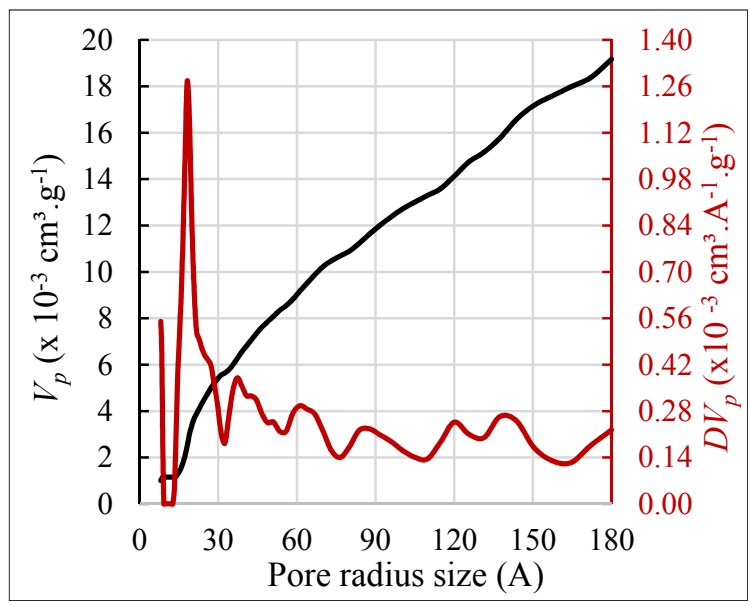

Figure 3. Cumulative pore volume (Vp) and differential volume (DVp) of IOT

\subsection{Analysis of Mortar Properties}

\subsubsection{Consistency-Flow Table}

From the results presented in Figure, it is clear that increasing the percentage of IOT addition in the mixtures does not cause major changes in this property. For additions of up to $10 \%$ IOT, the reduction in mortar spreading $(1 \%)$ is not as expressive from a workability point of view. The effects of the incorporation of IOT into this property are more evident from the $20 \%$ IOT addition, and for the $40 \%$ IOT addition there is a $7 \%$ reduction in the spreading condition in relation to the reference trait (without addition of IOT). This result is attributed to the increase in the percentage of fine material. As the water/cement factor remained fixed, there was a small reduction in workability with the addition of IOT, but this relative higher demand for water was not considered significant. Fontes et al. (2016) observed a similar behavior, attributing it to the very fine particle size of the tailings, which helps the plasticity of the composite. 


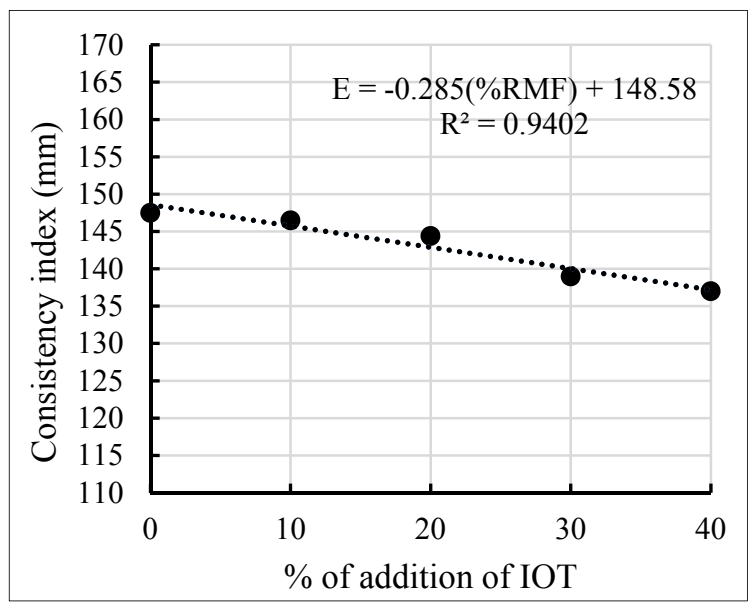

Figure 4. Determination of consistency index

Understanding the need for water to maintain workability is important, as it is known that excess water, although increasing the workability of Portland cement mortars, is deleterious, weakening the final mechanical strength of the hardened product (Souza, Carvalhais \& Santos, 2020). Depending on the IOT addition content in mortar production, the spreading results indicate the use of chemical additives (possibly plasticizers), which could guarantee the ease of application, handling and good finishing of cementitious composites. However, in this work, no type of additive was used, and the mortar was always in the plastic state. The low porosity of IOT and the high fineness tend to enhance their use with a focus on increasing durability due to the packaging effect closing the voids without requiring more kneading water because of its larger specific area.

\subsubsection{Water Absorption by Immersion and Porosity}

Water absorption and void index results are given in Figures 5 and 6. The void index in structural mortars varies according to the percentage of IOT addition, and the lower void index of the mortar with $30 \%$ IOT addition decreased by $7 \%$ compared to the reference.

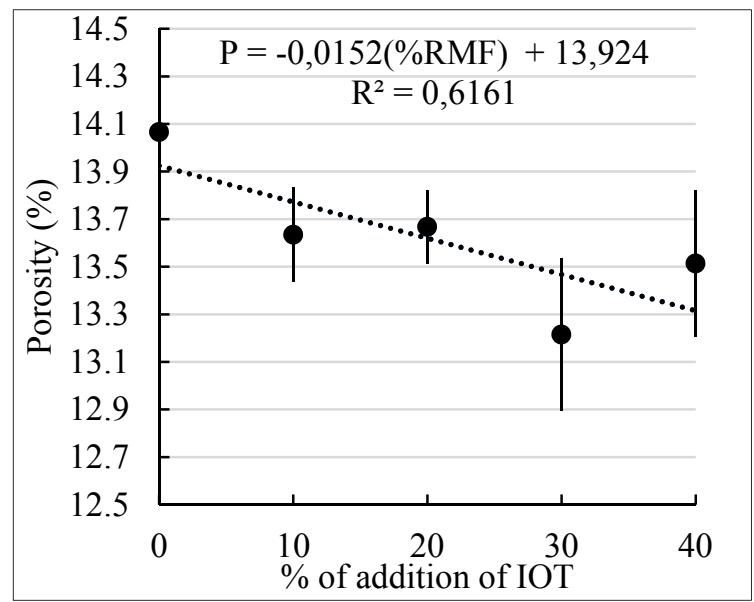

Figure 5. Surface porosity of structural mortars

This result is also observed for water absorption (Figure 6), i.e., a 5\% reduction in absorption capacity. Therefore, there is a reduction in total permeable pores in the mortars with the addition of tailings, demonstrating a gradual pore closing effect caused by IOT additions with a good correlation $\left(\mathrm{R}^{2}>0.95\right)$ due to the high fineness and low porosity of tailings contributing to this result (Figure 5). Thus, the addition of IOT may indicate a good durability to structural parts from the perspective of fluid permeability and aggressive agents. 


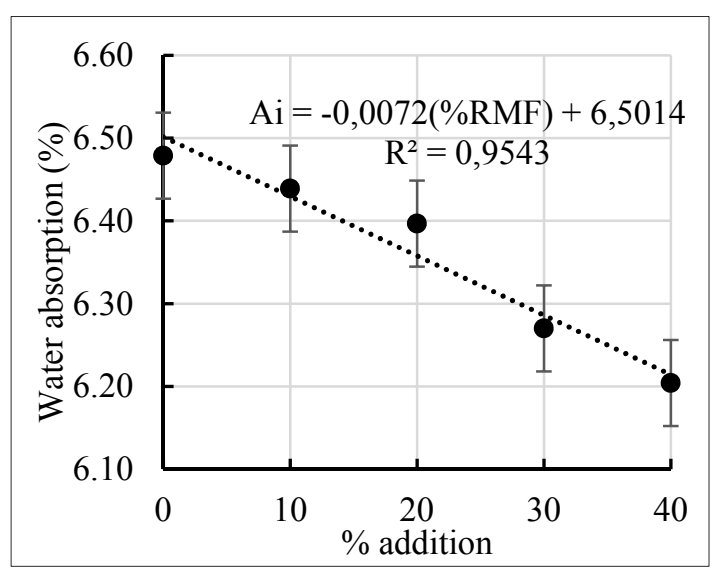

Figure 6. Water absorption by structural mortars

In the images of Figure 7, it is possible to observe that with the increase in the addition content, the pores reduce their diameter, which suggests a pore refinement besides the reduction of the connectivity between them, corroborating the results of porosity and water absorption. Nevertheless, the excess of thin materials can impair the workability and the density of the layers, as observed in the results for the consistency index.

Figure 8 (a-h) shows the images obtained by scanning electron microscopy (SEM). A similar morphology of pastes is noticed, with pores within the range 103-203 $\mu \mathrm{m}$ verified in both [Figure 8-a, b, c, d], and several pores within the range of $0.5 \mu \mathrm{m}$. Within the larger pores, one can identify the formation of portlandite $\left(\mathrm{Ca}(\mathrm{OH})_{2}\right)$ in both pastes [Figure $8-a, b, c, d]$, but the presence of larger scale ettringite was found in the reference paste alone (about $30 \mu \mathrm{m}$ ) [Figure 8 -a and c]. In the paste containing IOT, ettringite was identified only at smaller dimensions (approximately $8 \mu \mathrm{m}$ ) [Figure 8-g and $\mathrm{h}$ ]. The presence of C-S-H was verified in both samples, but visible only at larger scales $(2 \mu \mathrm{m})$. 

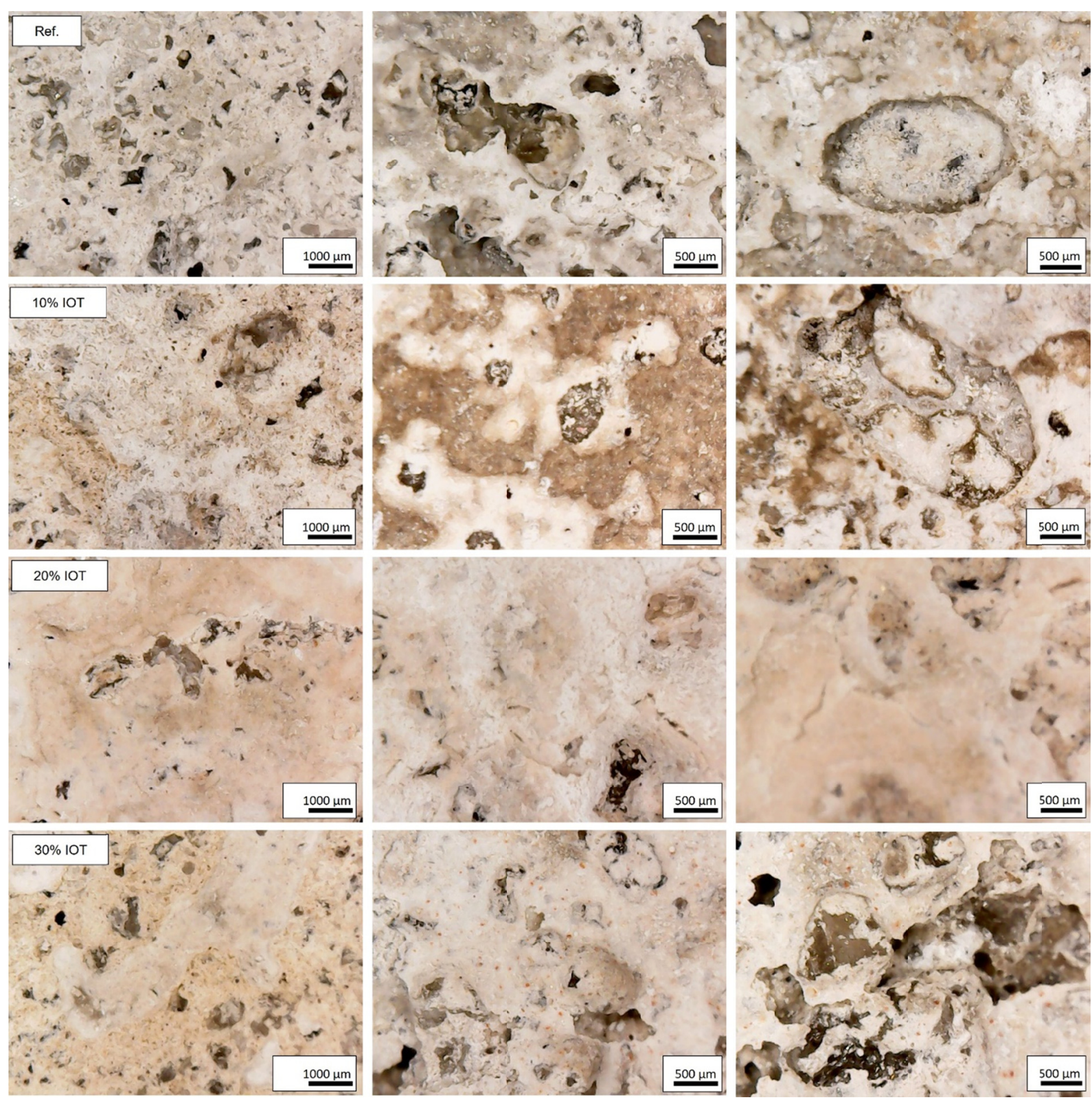

Figure 7. Digital microscopy of specimens 

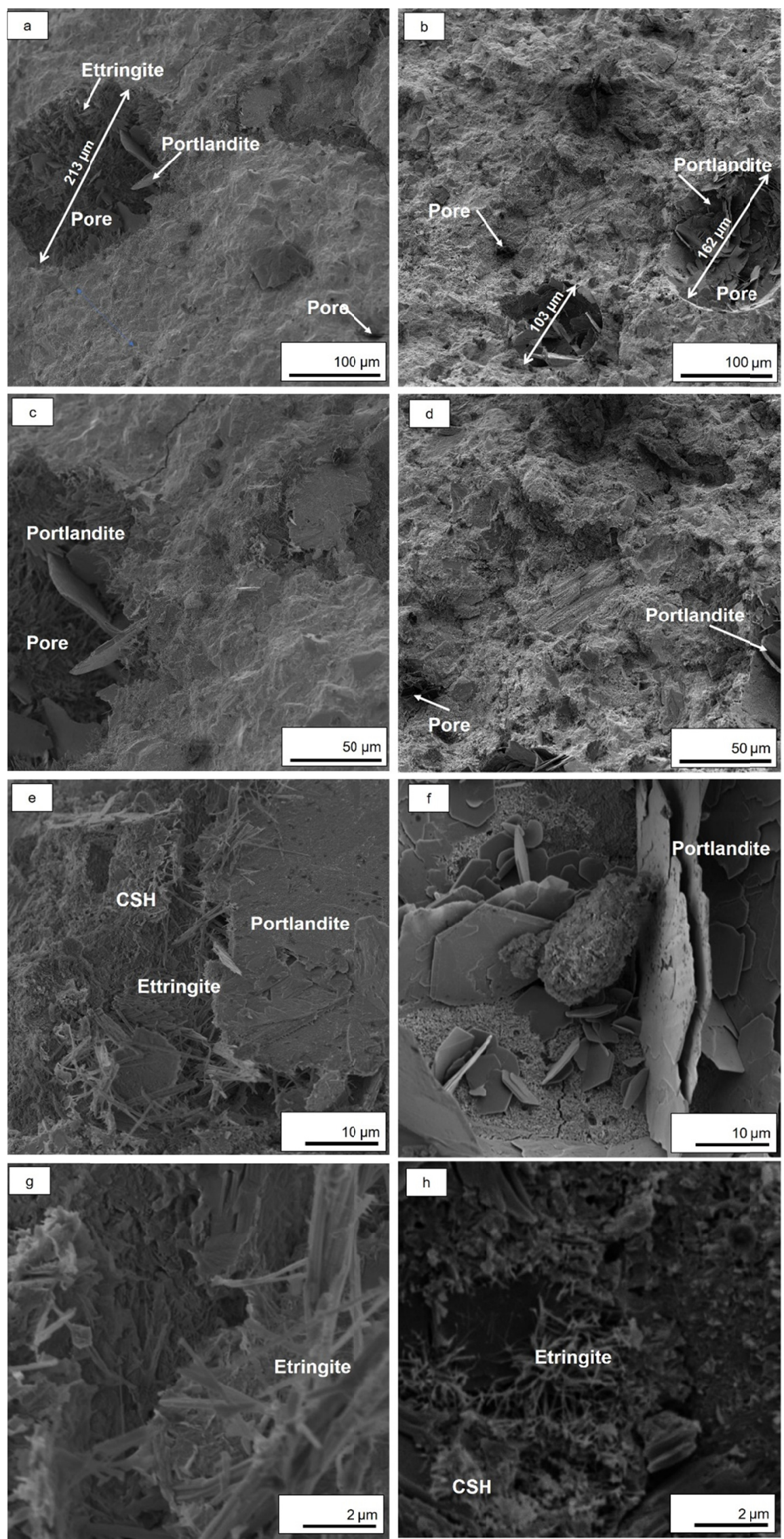

Figure 8. Microstructural analysis of pastes by scanning electron microscopy: (a, c, e, g) - Reference e (b, d, f, h) IOT 


\subsubsection{Tensile Strength at Flexion and Compression}

Figures 9 and 10 show the results of flexural tensile and compression tests at ages seven and 28 days. The flexural tensile strength at the age of seven days in all traces with IOT addition tends to decrease, being more significant in mortar with $30 \%$ IOT addition (19\%). However, at 28 days, the tensile strength remains constant, except for the mortar with $10 \%$ IOT, which presented a resistance gain of $10 \%$. Upon studying the paste containing IOT microscopically (Figure 8), there was the formation of hydrated cement compounds (Portlandite, $\mathrm{C}-\mathrm{S}-\mathrm{H}$ and ettringite) at reduced sizes (approximately four times smaller), which could be associated with such a loss of tensile strength.

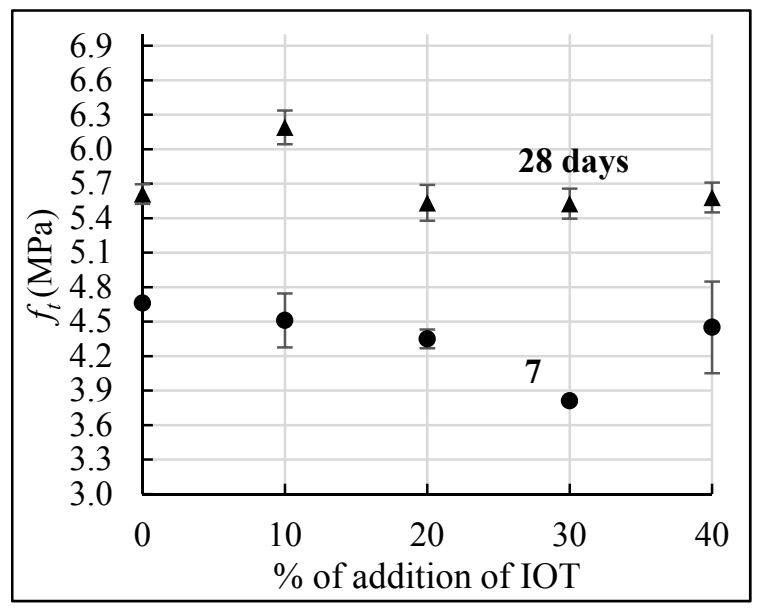

Figure 9. Flexural tensile strength (ft) for ages seven and 28 days

In general terms, the results obtained converge with some previous studies, such as the works of (Fontes et al., 2016; Aristimunho \& Bertocini, 2012) who replaced sand and in which the IOT composite mixtures showed a good behavior regarding flexural tensile strength due to involvement of tailings grains for cement hydration products. In the case of use as IOT addition in mortars, a reduction in tensile strength at early ages is observed. However, these mortars achieved results equal to or higher than the reference at 28 days. It is noteworthy that this comparative analysis aims to establish behavioral lines regarding the presence and quantity of IOT applied the methods of application of IOT differ in each study. With these results, IOT do not change this property and can be admitted up to higher levels than those evaluated in this research, provided they are previously measured.

The compressive strength at 28 days (Figure 10) shows the growth tendency with the addition of tailings, especially at higher levels, with a gain of $14 \%$ for mortar with $40 \%$ IOT addition. However, for additions of up to $20 \%$ IOT, there is a slight decrease in resistance at the early days (up to $5 \%$ ), suggesting that hydration reactions are slower in IOT mortars. These results corroborate those of Fontes et al. (2016). The author reported traces composed of tailings that showed a good compression behavior (also at $40 \%$ ). However, the results differ from Aristimunho and Bertocini (2012), who found loss of compressive strength for the addition of $20 \%$ IOT and strength gains only for contents up to $10 \%$ IOT. 


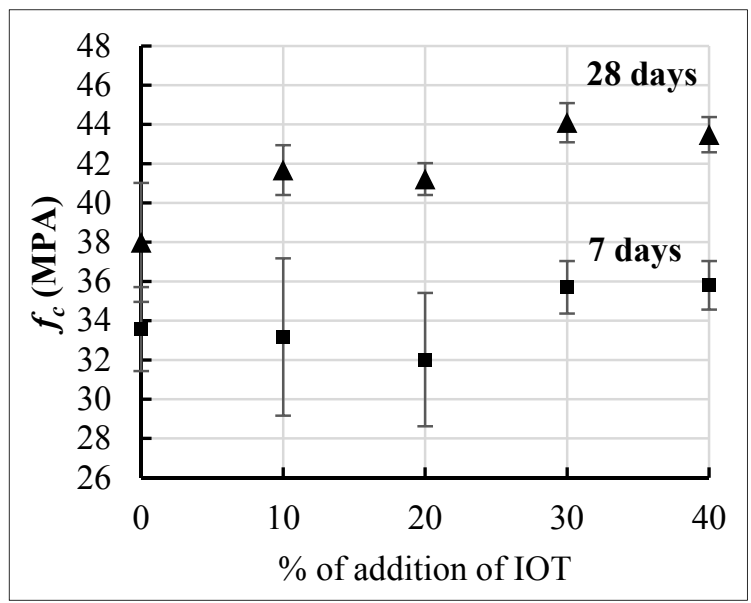

Figure 10. Compressive strength (fc) for the ages seven and 28 days

The strength gain can be explained by the better particle packing caused by the filler effect as observed for the absorption and void index results. In general, when the void index and, consequently, the porosity index decrease, the compressive strength (Souza, Barbosa, Riccio, \& Santos, 2020). In addition, increased nucleation points for formation of hydrated cement compounds due to the fineness of the material may have contributed to this result.

It is important to note that micro-concretes manufactured with all IOT addition contents meet the minimum mechanical conditions for use as structural concrete from $20 \mathrm{MPa}$, according to the ABNT (2015b). With the addition of IOT to structural mortars, there is a decrease in cement consumption. Therefore, its use is beneficial both technically and environmentally.

\subsubsection{Bulk Density}

It is observed that IOT provides a small increase in bulk density of mortars (Figure 11). This increase is gradual, with the $40 \%$ IOT addition being only $3 \%$ denser than the reference characteristic.

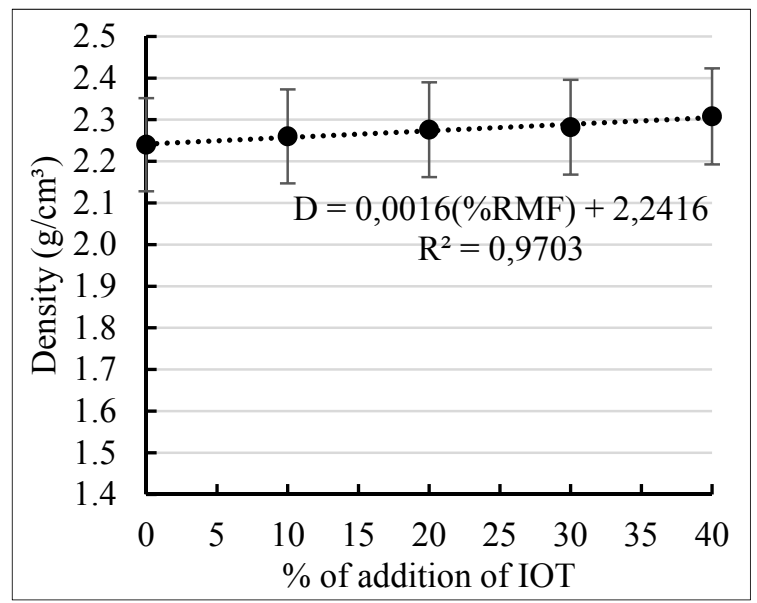

Figure 11. Density of structural mortar

Statistically, considering the error bar, the density values are the same for all mortars. Comparing the results obtained with the bulk density of conventional concretes, which, according to Haddad et al. (2020), are between 2.3 and $2.5 \mathrm{~g} / \mathrm{cm}^{3}$, it is inferred that the micro-concrete produced with the addition of IOT could be applied to structural functionalities and not only in ground-supported structures, not causing significant excess overload on the structures.

\subsubsection{Carbonation}

The accelerated carbonation results (Figure 12) show that the reference specimen had a maximum carbonation depth of $2 \mathrm{~mm}$, and the specimen containing $40 \%$ IOT addition had a maximum of $4 \mathrm{~mm}$. 


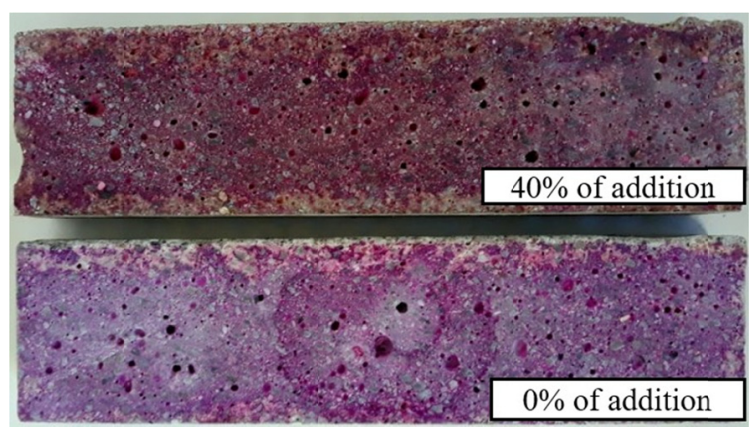

Figure 12. Result of accelerated carbonation of mortars with and without IOT

However, the highest carbonation depths in both mortars occurred near the surface of the specimen that was not in contact with the formwork, where porosity is slightly higher. At other edges, the carbonation was zero or close to $1 \mathrm{~mm}$. This is due to the decreased permeability of the composite by the filler effect of tailings, which made it difficult for $\mathrm{CO}_{2}$ to penetrate the specimen. Moreover, it can be inferred that in the hydration processes of cement in the mortar with the addition of IOT, there was the formation of compounds such as $\mathrm{Ca}(\mathrm{OH})_{2}$, which provide the environment with an alkaline $\mathrm{pH}$, necessary to prevent carbonation. Therefore, the addition of IOT does not significantly affect the behavior of structural mortars from a carbonation point of view, generating a material with characteristics suitable for structural use.

\section{Conclusion}

After the characterization of the materials, it can be concluded that tailings present predominantly the crystalline phases of quartz ( $\mathrm{SiO}$ ), hematite ( $\mathrm{Fe} \mathrm{O}$ ), goethite, not being found chemical or mineralogical components that could compromise the quality of cementitious composites with possible deleterious reactions. The physical properties evidence a high specific mass material of IOT $\left(4.04 \mathrm{~g} / \mathrm{cm}^{3}\right)$ and a high fineness after comminution (surface area of $7.79 \mathrm{~m}^{2} / \mathrm{g}$ ). However, it did not require significantly more kneading water due to the reduced porosity $(0.036 \mathrm{cc} / \mathrm{g})$, proving to be a material with a great potential to act as a filler.

Upon analyzing pastes and mortars, the formation of portlandite $\left(\mathrm{Ca}(\mathrm{OH})_{2}\right)$ inside larger pores in the reference traces and with the addition of IOT and the reduction of ettringite crystals with the introduction of IOT was identified. In the fresh state, the residual mortars showed a similar workability as the reference mortar, indicating that there are no significant effects on water demand. In the hardened state, there is a good mechanical behavior in flexural traction (maintenance of values) and a great result in compression (up to $14 \%$ increase). From the hardness density results, it can be concluded that the micro-concrete produced with the addition of IOT could be used for structural functionalities, causing no significant increases in structural overload since it increased not over $3 \%$. The void index and water absorption index of IOT-containing mortars decreased, and there is a refinement and pore filling effect, which indicates a better durability behavior due to the filler effect.

We conclude from the results that it is possible to add IOT up to $40 \%$ with the maintenance or improvement of properties, both fresh and hardened. Its addition could reduce the consumption of composite materials, including cement, making the product potentially more economical for use in construction.

\section{References}

Abdulrahman, H. S. (2015). Potential use of iron ore tailings in sandcrete block making. International Journal of Research in Engineering and Technology, 4(4), 409-414. https://doi.org/10.15623/ijret.2015.0404073

ABNT. (2004). NBR 10004: Solid waste-Classification. Rio de Janeiro.

ABNT. (2005a). NBR 13278: Mortars applied on walls and ceilings-Determination of the specific gravity and the air entrained content in the fresh stage. Rio de Janeiro.

ABNT. (2005b). NBR 13279: Mortars applied on walls and ceilings-Determination of the flexural and the compressive strength in the hardened stage. Rio de Janeiro.

ABNT. (2009). NBR 9778: Hardened mortar and concrete—Determination of absorption, voids and specific gravity. Rio de Janeiro.

ABNT. (2015a). NBR 7214: Standard sand for cement tests—Specification. Rio de Janeiro. 
ABNT. (2015b). NBR 8953: Concrete for structural use-Density, strength and consistence classification. Rio de Janeiro.

ABNT. (2016a). NBR 7181: Soil-Grain size analysis. Rio de Janeiro.

ABNT. (2016b). NBR 13276: Mortars applied on walls and ceilings-Determination of the consistence index. Rio de Janeiro.

ABNT. (2018). NBR 16697: Portland cement-Requirements. Rio de Janeiro.

Almada, B. S., Melo, L. de S., Dutra, J. B., Bubani, L. C., Silva, G. J. B., Santos, W. J. dos, \& Aguilar, M. T. P. (2020). Influence of the heterogeneity of waste from wet processing of ornamental stones on the performance of Portland cement composites. Construction and Building Materials, 262, 120036. https://doi.org/10.1016/j.conbuildmat.2020.120036

ANM. (2018). National Mining Agency. Brazilian Mineral Yearbook: Main metallic substances. Retrieved August 13, 2019, from http://www.anm.gov.br.

Aristimunho, P. B., \& Bertocini, S. R. (2012). Application of iron ore mud in powder form in portland cement presence. IBRACON Structures and Materials Journal, 5(2), 153-165. https://doi.org/10.1590/S1983-41952012000200003

Campanha, A. (2011). Characterization of iron ore tailings for use in paving. Masters Dissertation. Federal University Federal of Viçosa, Viçosa, Brazil.

Cancio, A. S., Coelho, J. R. C., Duarte, M. S., Almada, B. S., Paula, F. G., \& Santos, W. J. D. (2018). Study of the Reuse of Iron Ore Tailing in Cementitious Compounds. International Journal of Science and Engineering Investigations, 7(77), 148-153.

Carrasco, E. V. M., Magalhaes, M. D. C., Santos, W. J. D., Alves, R. C., \& Mantilla, J. N. R. (2017). Characterization of mortars with iron ore tailings using destructive and nondestructive tests. Construction and Building Materials, 131, 31-38. https://doi.org/10.1016/j.conbuildmat.2016.11.065

Castro, A. L. de, Liborio, J. B. L., \& Pandolfelli, V. C. (2009). Performance of advanced concretes for building site designed by computing mix proportion technique. Cerâmica, 55(335), 233-251. https://doi.org/10.1590/S0366-69132009000300002

Costa, A. V., Gumieri, A. G., \& Brandão, P. R. G. (2014). Interlocking concrete blocks produced with sinter feed

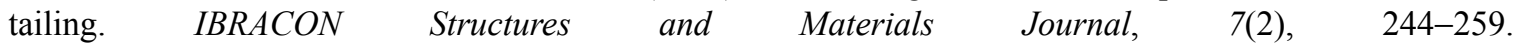
https://doi.org/10.1590/S1983-41952014000200004

Dauce, P. D., Castro, G. B. De, Lima, M. M. F., \& Lima, R. M. F. (2019). Characterisation and magnetic concentration of an iron ore tailings. Journal of Materials Research and Technology, 8(1), 1052-1059. https://doi.org/10.1016/j.jmrt.2018.07.015

DNER. Department of Roads Running. (1994). ME 093: Solos - Determinação da densidade real.

Ferreira, K. C., Aguiar, M. A. M., Oliveira, M. F. M., Silva, A. Q. N., \& Peres, E. A. E. C. (2016). Iron ore residue use as raw materials for the manufacture of mortar. Holos, 2(32), 22-83.

Florindo, R. N. (2009). Study of alkali-silica reaction gel in concrete by high-resolution nuclear magnetic resonance. Masters Dissertation. University of São Paulo, São Paulo, Brazil.

Fontes, W. C., Franco de Carvalho, J. M., Andrade, L. C. R., Segadães, A. M., \& Peixoto, R. A. F. (2019). Assessment of the use potential of iron ore tailings in the manufacture of ceramic tiles: From tailings-dams to "brown porcelain." Construction and Building Materials, 206, 111-121. https://doi.org/10.1016/j.conbuildmat.2019.02.052

Fontes, W. C., Mendes, J. C., Da Silva, S. N., \& Peixoto, R. A. F. (2016). Mortars for laying and coating produced with iron ore tailings from tailing dams. Construction and Building Materials, 112, 988-995. https://doi.org/10.1016/j.conbuildmat.2016.03.027

Galvão, J. L. B., Andrade, H. D., Brigolini, G. J., Peixoto, R. A. F., \& Mendes, J. C. (2018). Reuse of iron ore tailings from tailings dams as pigment for sustainable paints. Journal of Cleaner Production, 200, 412-422. https://doi.org/10.1016/j.jclepro.2018.07.313

G1. (2015). Tailings from dams reach areas up to $100 \mathrm{~km}$ in $M G$. Retrieved November 20, 2019, from http://g1.globo.com/minas-gerais/noticia/2015/11/hidreletrica-100-km-e-afetada-por-lama-do-rompimentode-barragens.html 
Haddad, L. D. de O., Neves, R. R., Oliveira, P. V. de, Santos, W. J. dos, Carvalho Junior, A. N. de, \& Santos, W. J. dos. (2020). Influence of particle shape and size distribution on coating mortar properties. Journal of Materials Research and Technology, 9(4), 9299-9314. https://doi.org/10.1016/j.jmrt.2020.06.068

IBRAM. (2018). Mineral Economy of Brazil. Retrieved August 13, 2019, from https://portaldamineracao.com.br/wp-content/uploads/2018/02/economia-mineral-brasil-mar2018-1.pdf?x73 853

Jena, S. K., Sahoo, H., Rath, S. S., Rao, D. S., Das, S. K., \& Das, B. (2015). Characterization and processing of iron ore slimes for recovery of iron values. Mineral Processing and Extractive Metallurgy Review, 36(3), 174-182. https://doi.org/10.1080/08827508.2014.898300

Kuranchie, F. A., Shukla, S. K., Habibi, D., \& Mohyeddin, A. (2015). Utilisation of iron ore tailings as aggregates in concrete. Cogent Engineering, 2(1). https://doi.org/10.1080/23311916.2015.1083137

Magalhães, L. F., Morais, I. S., Esteves, M. A., Melo, JR, A. C., Maia, A. L. F., \& Bezerra, A. C. S. (2017). Resistance to acid attack of portland cement with addition of iron ore tailings. In 59th Brazilian Concrete Congress-IBRACON: Bento Gonçalves/RS.

Medeiros, M. H. F., Souza, D. J., Filho, J. H., Adorno, C. S., Quarcioni, V. A., \& Pereira, E. (2016). Red-clay waste and limestone filler added in Portland cement composite: effects on sulfate attack and alkali-silica reaction. Revista Materia, 21(2), 282-300. https://doi.org/10.1590/S1517-707620160002.0028

Osinubi, K. J., Yohanna, P., \& Eberemu, A. O. (2015). Cement modification of tropical black clay using iron ore tailings as admixture. Transportation Geotechnics, 5, 35-49. https://doi.org/10.1016/j.trgeo.2015.10.001

Shettima, A. U., Hussin, M. W., Ahmad, Y., \& Mirza, J. (2016). Evaluation of iron ore tailings as replacement for fine aggregate in concrete. Construction and Building Materials, 120, 72-79. https://doi.org/10.1016/j.conbuildmat.2016.05.095

Souza, A. T., Barbosa, T. F., Riccio, L. A., \& Santos, W. J. dos. (2020). Effect of limestone powder substitution on mechanical properties and durability of slender precast components of structural mortar. Journal of Materials Research and Technology, 9(1), 847-856. https://doi.org/10.1016/j.jmrt.2019.11.024

Souza. A. T., Carvalhais, C. A., \& Santos, W. J. dos. (2020). Analysis of chemical admixtures combination on coating mortar using Simplex network method. Construction and Building Materials, 239, 117796. https://doi.org/10.1016/j.conbuildmat.2019.117796

Srivastava, A., Vidisha, S. A. T. I., Joshi, D. Y. P., Vidisha, S. A. T. I., Nagayach, S., \& Bhopal, S. I. R. T. (2016). Concrete using red-mud and iron-ore slickens. International Journal of Scientific Research and Development, 4(3), 1856-1858.

Ugama, T. I., \& Ejeh, S. P. (2014). Iron ore tailing as fine aggregate in mortar used for masonry. International Journal of Advances in Engineering \& Technology, 7(4), 1170-1178.

Ullas, S. N., \& Venkatarama, R. B. V. (2010). Iron ore tailings as substitute for sand in masonry mortar (pp. 151-155). Proceedings of the International Seminar on Waste to Wealth.

Zhao, S., Fan, J., \& Sun, W. (2014). Utilization of iron ore tailings as fine aggregate in ultra-high performance concrete. Construction and Building Materials, 50, 540-548. https://doi.org/10.1016/j.conbuildmat.2013.10.019

\section{Copyrights}

Copyright for this article is retained by the author, with first publication rights granted to the journal.

This is an open-access article distributed under the terms and conditions of the Creative Commons Attribution license (http://creativecommons.org/licenses/by/4.0/). 